\title{
Pola Asuh Permisif dan Otoriter Orang Tua terhadap Perilaku Seks Bebas pada Remaja di SMK Prima Bakti Citra Raya
}

\author{
Nurry Ayuningtyas Kusumastuti ${ }^{*}$, Fatimah Indriastuti ${ }^{2}$ \\ 1,2Program Studi Keperawatan, STIKes YATSI Tangerang, Tangerang, Banten, 15114, Indonesia \\ *Email: nurry0067@gmail.com
}

\begin{abstract}
Abstrak: Perilaku seks bebas di kalangan remaja menimbulkan dampak negatif terhadap kesehatan reproduksi remaja, khususnya kehamilan di luar nikah. Penyebab utama dari perilaku seks bebas adalah pola asuh orang tua yang salah. Terdapat tiga macam pola asuh orang tua. Pola asuh permisif membuat anak menjadi lebih bebas melakukan hal-hal negatif karena memberikan kebebasan pada anak tanpa pengawasan. Sedangkan, pola asuh otoriter dapat menyebabkan anak menjadi merasa tertekan dan ketakutan karena membatasi pergaulan anak dan memaksakan kehendak orang tua. Pola asuh yang mengkombinasikan keduanya adalah pola asuh demokratis yang menerapkan komunikasi dan kerjasama yang baik antara anak dan orang tua, sehingga anak menjadi lebih terbuka dan memiliki rasa tanggung jawab. Tujuan penelitian untuk mengetahui perbedaan antara pola asuh permisif dan otoriter orang tua terhadap perilaku seks bebas pada remaja di SMK Prima Bakti Citra Raya tahun 2020. Metode penelitian: Menggunakan desain Komparatif dengan jumlah sampel 100 responden yang diambil dengan teknik Simple Random Sampling. Instrumen yang digunakan adalah kuesioner yang dimasukkan ke dalam google formulir, dan menggunakan uji Chi Square. Hasil penelitian: Menunjukkan nilai $(\mathrm{p}=0.014<0.05)$, perbedaan tersebut terlihat dari pola asuh permisif yang lebih rendah 0.813 dibandingkan pola asuh otoriter 5.8. Kesimpulan: ada perbedaan yang signifikan antara pola asuh permisif dan otoriter orang tua terhadap perilaku seks bebas pada remaja di SMK Prima Bakti Citra Raya tahun 2020.
\end{abstract}

Kata Kunci: Pola asuh, permisif, otoriter, perilaku seks bebas, remaja.

Abstract: Free sex behavior among adolescents has a negative impact on adolescent reproductive health, especially pregnancy outside of marriage. The main cause of free sex behavior is the wrong parenting style. There are three kinds of parenting styles. Permissive parenting makes children freer to do negative things because it gives children freedom without supervision. Meanwhile, authoritarian parenting can cause children to feel depressed and afraid because they limit children's interactions and impose their parents' will. The best choice about type of parenting is a combination of both, namely is democratic parenting that applies good communication and cooperation between children and parents, so that children feel free to share and have a sense of responsibility. Purposes: this study aimed to determine of the differences in parent perfective and authoritary parents to adolescent free sex in vocational school of Prima Bakti Citra Raya, 2020. Method: This study used a comparative design with 100 respondents using Simple Random Sampling design. The data was collected by using a questionnaire that was entered into the google form. The difference of dependent variables between the two groups were tested by Chi-Square. Results : The result of this study was statistically significant ( $p=0.014<0.05$ ) with an OR value of 0.813 , permissive parenting pattern have a risk of 0.8 times lower than free sex behavior in adolescent and for authoritarian parenting parents has 5.8 times greater risk of free sex in adolescent. Conclusion: So, it can be concluded that there is a significant between permissive parenting and authoritarian parenting to adolescent free sex in vocational school of Prima Bakti Citra Raya 2020. 
Keywords: Parenting style, permissive, authoritarian, free sex behavior, adolescent

\section{PENDAHULUAN}

Masa remaja sering disebut dengan masa "mencari jati diri" karena remaja belum dapat memfungsikan dan menguasai secara maksimal fungsi fisik maupun fungsi psikisnya. Keadaan itu membuat remaja memiliki emosi yang lebih tinggi karena belum mampu mengendalikan diri dengan sempurna, sehingga sangat rentan dengan berbagai pengaruh dari lingkungan pergaulan termasuk dengan perilaku seksualnya (Sarono, 2011)

Prevalensi perilaku seks bebas di negara Amerika Serikat pada tahun 2018, terdapat sekitar $21 \%$ kasus yang menimbulkan diagnosis HIV baru. Pada remaja laki-laki sekitar $87 \%$ dan pada wanita sekitar 13\%, lalu setengah dari 20 juta PMS baru di negara Amerika Serikat merupakan siswa SMA yang berusia 15-24 tahun. Lalu sekitar 41\% siswa SMA pernah melakukan hubungan seksual dan hampir 180.000 bayi lahir dari remaja putri yang berusia 15-19 tahun (Department of Health and Human Service, 2018). Indonesia merupakan salah satu negara berkembang yang ada di dunia. Perilaku seks menyimpang di negara berkembang sekitar 12 juta remaja perempuan yang berusia 15-19 tahun yang mengalami kehamilan dan sekitar 49\% merupakan kehamilan yang tidak diinginkan. Kehamilan tersebut merupakan salah satu penyebab yang ditimbulkan dari perilaku seks menyimpang yang dilakukan sebelum pernikahan (World Health Organization, 2017).

Ketua Divisi dan Riset Lembaga Perlindungan Anak remaja (2015) mengatakan bahwa kehamilan yang ditimbulkan akibat perilaku seks bebas pada remaja di Jawa Timur mengalami peningkatan dari tahun 2014 terdapat 23 kasus, kemudian pada tahun 2015 mengalami peningkatan menjadi 30 kasus (Ahiyanasari, 2018). Sedangkan menurut Badan Kependudukan Keluarga Berencana Nasional (2010), sekitar 51\% remaja yang ada di wilayah Jabodetabek sudah kehilangan keperawanannya pada usia 13-15 tahun. Kejadian perilaku seks pranikah di Surabaya mencapai 47\%, di Bandung, Medan sekitar 52\% dan Papua sekitar 98\% (Rahmawati, 2018). Menurut Survei Demografi dan Kesehatan Indonesia didapatkan sekitar 3,2 juta remaja berusia 15-19 tahun memiliki risiko tinggi terhadap perilaku seksualnya, yaitu remaja yang memiliki gaya berkencan tidak sehat seperti berciuman, berpelukan hingga melakukan hubungan seksual (SDKI, 2017). Menurut Rahmawati (2018) menyatakan bahwa di Indonesia sekitar 97\% remaja SMA mengaku suka menonton film porno, sekitar 93,7\% pernah berciuman, petting, melakukan seks oral dan sekitar 21,2\% remaja SMA mengaku pernah melakukan aborsi.

Perilaku seks bebas pada remaja terjadi karena beberapa faktor yang dapat menyebabkan remaja melakukan hubungan seksual, yaitu faktor religiusitas, faktor pola asuh orang tua, dan faktor tekanan dari teman sebaya. Dari pernyataan tersebut didapatkan bahwa penyebab utama yang berhubungan dengan perilaku seks bebas pada remaja adalah pola asuh orang tua. Kecenderungan perilaku seksual remaja yang buruk dipengaruhi oleh pola asuh orang tua yang salah dalam mengasuh dan membesarkan anak. Menurut Survei Demografi dan Kesehatan Indonesia (2017) menyatakan bahwa semakin meningkatnya penyimpangan perilaku seks bebas di kalangan remaja akan menimbulkan dampak negatif terhadap kesehatan reproduksi remaja, khususnya remaja putri dan menyebabkan angka kehamilan usia remaja di luar nikah yang masih sangat tinggi. Kehamilan usia remaja di luar nikah tersebut yang menjadikan kasus aborsi untuk saat ini masih tinggi karena merupakan pilihan yang tidak bisa dihindarkan. Selain itu, perilaku seks bebas juga akan menyebabkan dampak fisiologis pada remaja, yaitu dapat mengakibatkan terjadinya penyakit menular seksual, seperti HIV/AIDS (Sarwono, 2011).

Hasil penelitian Pandensolang (2019), yang berjudul "Hubungan Pola asuh Orang tua dengan Perilaku Seksual pada Remaja di SMA negeri 1 Beo kepulauan Talaud", dari 93 responden menyatakan hasil uji Kolmogorov-smirnov 95\% tingkat kemaknaan didapat $0.003<0.05$, maka dapat disimpulkan bahwa terdapat hubungan antara pola asuh orang tua dengan perilaku seksual pada remaja. Sedangkan menurut (Suparni, 2015) menyatakan bahwa dari 76 responden menunjukkan ada hubungan positif yang terjadi antara pola asuh permisif dengan sikap seks bebas, dengan hasil $\mathrm{t}$ hitung $0.297<\mathrm{t}$ tabel 0.05 , maka rxy dinyatakan signifikan. Sehingga dapat disimpulkan semakin 
tinggi pola asuh permisif orang tua maka sikap perilaku seks bebas pada remaja juga akan semakin tinggi. Gaya pola asuh orang tua yang memberikan kebebasan pada anaknya dapat membuat anak melakukan hal yang mereka inginkan dengan sesuka hati tanpa adanya pengawasan orang tua itu sendiri dan cenderung melakukan pergaulan bebas. Kesalahan ataupun kenakalan yang saat ini banyak dilakukan oleh remaja, menjadi penyebab utama timbulnya perilaku, yaitu terletak pada kesalahan pola asuh orang tua selama usia perkembangan remaja (Juhardin, 2016).

Hasil penelitian menurut Puteri (2018) yang berjudul "Hubungan Pola Asuh Otoriter terhadap Perilaku Perundungan pada Remaja Tahun 2018",dari 272 responden menyatakan hasil p-value $0.00<0.05$. Sehingga, dapat disimpulkan bahwa pola asuh otoriter mempengaruhi perilaku perundungan.Sedangkan pada persamaan regresi didapatkan hasil $\hat{y}=39.99+0.48$ (pola asuh), sehingga semakin meningkatnya nilai pola asuh otoriter maka perundungan akan semakin meningkat.Berdasarkan hasil penelitian yang diperoleh, maka penerapan pola asuh memiliki peran penting dalam kehidupan seorang anak. Perilaku dan sikap yang ada pada seseorang merupakan hasil dari internalisasi nilai-nilai yang ditanamkan oleh orang tuanya sejak kecil. Pola asuh merupakan interaksi antara orang tua dengan anak, dimana orang tua berperan sebagai pemberi dorongan bagi anak dengan mengubah pengetahuan, tingkah laku, dan yang dianggap paling tepat bagi orang tua adalah agar anak bisa mandiri, memiliki rasa percaya diri yang tinggi, dapat tumbuh atau berkembang secara optimal dan berorientasi untuk sukses (Arub, 2017). Pola asuh orang tua ada 3 macam, yaitu pola asuh permisif, otoriter dan demokratis. Penggunaan pola asuh tersebut akan berpengaruh terhadap perbedaan tingkah laku pada masing-masing remaja baik itu berpengaruh positif maupun berpengaruh negatif (Triandika, 2015).

Perilaku seksual pada remaja dapat dicegah jika pola pengasuhan orang tua tepat pada anaknya, pola asuh yang disarankan adalah pola asuh demokratis. Karena pola asuh demokratis memiliki hubungan dengan perilaku seksual pranikah remaja, dimana remaja dengan pola asuh demokratis akan meniru orang tuanya dalam hal komunikasi terbuka sehingga dapat menurunkan perilaku seksual pranikah yang berisiko bagi masa depan mereka (Tridhonanto, 2018). Menurut SDKI (2017), mengatakan penanganan pencegah perilaku dari dampak seks pranikah juga bisa dilakukan dengan pendidikan kesehatan untuk mengetahui pentingnya pengetahuan dan informasi tentang kesehatan reproduksi, perilaku seks bebas dan cara pencegahannya untuk remaja.

Dari hasil studi pendahuluan di SMK Prima Bakti Citra Raya, peneliti melakukan wawancara dengan 5 orang perempuan mengatakan bahwa pola asuh orang tua mereka adalah memaksa/otoriter, sehingga cenderung menyebabkan anak menjadi tertekan dan merasa ketakutan, bahkan bisa membuat anak benci kepada orang tua. Pada 10 siswa laki-laki mengatakan pola asuh orang tua mereka sebagian besar di SMK Prima Bakti adalah cuek atau permisif membebaskan anaknya melakukan sesuatu dan lebih mementingkan pekerjaannya dibanding anaknya. Pola asuh permisif cenderung menjadikan anak merasa tidak berarti, rendah diri, kurang menghargai orang lain dan emosian terhadap teman sebaya sehingga perhatian orang tua kepada anak berkurang dengan perhatian yang kurang, maka anak akan lebih bebas melakukan hal-hal negatif. Berdasarkan uraian sebelumnya peneliti tertarik untuk melakukan penelitian mengenai perbedaan pola asuh permisif dan otoriter orang tua terhadap perilaku seks bebas remaja. Oleh karena itu, peneliti tertarik untuk meneliti " Perbedaan pola asuh permisif dan otoriter orang tua terhadap perilaku seks bebas pada remaja di SMK Prima Bakti Citra Raya Tahun 2020".

\section{METODE}

Penelitian ini merupakan jenis penelitian kuantitatif dengan menggunakan pendekatan cross sectional dan menggunakan desain komparatif karena penelitian ini bertujuan untuk membandingkan antara kedua variabel independen (pola asuh permisif dan otoriter) orang tua dengan variabel dependen (perilaku seks bebas) pada remaja. Penelitian ini dilaksanakan pada tanggal 18 April 2020. Populasi dalam penelitian ini adalah kelas 11 yang berjumlah 120 responden, sedangkan pengambilan sampel pada penelitian ini menggunakan teknik Simple Random Sampling dengan rumus Slovin. Hasil yang didapatkan, yaitu sebanyak 100 responden yang telah memenuhi kriteria inklusi. 
Dalam penelitian ini instrumen yang digunakan adalah kuesioner yang dimasukkan ke dalam google formulir yang sudah di uji validitas dan reliabilitas. Terdapat 2 kategori dalam kuesioner, yang pertama kuesioner mengenai pola asuh orang tua yang berisi 15 pertanyaan menggunakan skala likert dengan penilaian jawaban Sangat Setuju 4, Setuju 3, Tidak Setuju 2 dan Sangat Tidak Setuju 1 serta menggunakan nilai hasil ukur pola asuh orang tua permisif jika $>30$ dan pola asuh orang tua otoriter jika $\leq 30$, yang kedua kuesioner perilaku seks bebas yang berisi 10 pertanyaan menggunakan skala guttman dengan penilaian jawaban Pernah 1, Tidak Pernah 0 serta menggunakan hasil ukur perilaku seks bebas tidak baik jika $>5$ dan perilaku seks bebas baik jika $\leq 5$ yang diadopsi dari Devi (2015).

Pengolahan data hasil penelitian ini menggunakan komputer dan diolah menggunakan SPSS, lalu dianalisis dan disajikan ke dalam bentuk analisis univariat dan bivariat. Tahap pengolahan data pada penelitian ini yaitu, Editing, Coding, Processing (entry data), dan Cleaning. Analisis bivariat pada penelitian ini adalah untuk mengetahui perbedaan pola asuh permisif dan otoriter orang tua terhadap perilaku seks bebas pada remaja di SMK Prima Bakti Citra Raya tahun 2020. Skala ukur dalam penelitian ini adalah skala nominal dan ordinal, maka uji statistik yang digunakan adalah Uji Chi Square.

\section{HASIL}

Berdasarkan hasil penelitian yang sudah dilaksanakan, maka dapat ditampilkan tabel 1 yang menjelaskan data jenis pola asuh orang tua pada remaja di SMK Prima Bakti Citra Raya. Tabel 1 menyajikan jumlah dan persentase kategori pola asuh orang tua remaja di SMK Bakti Citra Raya tahun 2020

Tabel 1. Distribusi berdasarkan Pola asuh Permisif dan Otoriter Orang tua terhadap Perilaku Seks Bebas pada Remaja di SMK Prima Bakti Citra Raya Tahun 2020.

\begin{tabular}{ccc}
\hline Pola Asuh Orang Tua & Jumlah & Persentase(\%) \\
\hline Pola Asuh Permisif & 88 & $88 \%$ \\
Pola Asuh Otoriter & 12 & $12 \%$ \\
\hline Total & 100 & $100 \%$ \\
\hline
\end{tabular}

Hasil penelitian menunjukkan bahwa mayoritas pola asuh orang tua responden yang memiliki pola asuh permisif adalah sebanyak 88 orang sedangkan yang memiliki pola asuh otoriter sebanyak 12 orang.

Pada tabel 2 dapat dilihat hasil distribusi perilaku tentang seks bebas pada remaja di SMK Bakti Citra Raya. Sebanyak 100 remaja sesuai subyek penelitian dikategorikan dalam dua kelompok yaitu kategori perilaku tidak baik dan baik.

Tabel 2. Distribusi berdasarkan Perilaku Seks Bebas pada Remaja di SMK Prima Bakti Citra Raya Tahun 2020.

\begin{tabular}{ccc}
\hline Kategori & Jumlah & Persentase (\%) \\
\hline Tidak Baik & 54 & $54 \%$ \\
Baik & 46 & $46 \%$ \\
\hline Total & 100 & $100 \%$ \\
\hline
\end{tabular}


Selanjutnya pola asuh orang tua dihubungkan dengan perilaku seks bebas remaja dan dipresentasikan pada tabel 3. Adapun untuk menyajikan perbedaan pola asuh permisif dan otoriter orang tua maka disajikan hasil analisa bivariat dengan menuliskan tabulasi silang dan nilai Odds Ratio (OR).

Tabel 3. Perbedaan Pola asuh Permisif dan Otoriter Orang tua terhadap Perilaku Seks Bebas pada Remaja di SMK Prima Bakti Citra Raya Tahun 2020.

\begin{tabular}{ccccccc}
\hline $\begin{array}{c}\text { Pola Asuh } \\
\text { Orang Tua }\end{array}$ & \multicolumn{2}{c}{ Perilaku Seks Bebas } & Total & OR & Median & P-Value \\
\cline { 2 - 4 } & Tidak baik & Baik & & & & \\
\hline Permisif & 52 & 36 & 88 & 0.813 & 2.00 & 0.014 \\
Otoriter & 2 & 10 & 12 & 5.870 & & \\
\hline Total & 54 & 46 & 100 & & & \\
\hline
\end{tabular}

Hasil penelitian menunjukkan bahwa dari 100 responden didapat sebanyak 52 responden dengan pola asuh permisif memiliki perilaku seks bebas tidak baik, 36 responden dengan pola asuh permisif memiliki perilaku seks bebas baik, untuk pola asuh otoriter sebanyak 2 responden memiliki perilaku seks bebas tidak baik dan 10 responden memiliki perilaku seks bebas baik. Dari hasil nilai OR 0.813 maka pola asuh permisif orang tua memiliki 0.8 kali lebih rendah terhadap perilaku seks bebas pada remaja. Sedangkan untuk pola asuh otoriter orang tua memiliki 5.8 kali lebih besar terhadap perilaku seks bebas pada remaja.

Hasil uji Chi-Square dengan nilai p-value 0.014 sehingga dapat disimpulkan bahwa ada perbedaan pola asuh permisif dan otoriter orang tua jika dihubungkan dengan perilaku seks bebas pada Remaja di SMK Prima Bakti Citra Raya Tahun 2020.

\section{PEMBAHASAN}

Berdasarkan hasil penelitian dapat diketahui bahwa data distribusi pola asuh permisif orang tua paling banyak yaitu, 88 responden, sedangkan pola asuh otoriter lebih sedikit, yaitu 12 responden. Dari penelitian (Pandensolar, 2019), didapatkan hasil $0.003<0.05$, maka dapat disimpulkan bahwa terdapat hubungan antara pola asuh orang tua dengan perilaku seksual pada remaja. Sedangkan, menurut (Suparni, 2015), menyatakan bahwa dari 76 responden menunjukkan ada hubungan positif yang terjadi antara pola asuh permisif dengan sikap seks bebas, dengan hasil $t$ hitung $0.297<t$ tabel 0.05 maka $r$ xy dinyatakan signifikan. Sehingga, dapat disimpulkan semakin tinggi pola asuh permisif orang tua, maka sikap perilaku seks bebas pada remaja juga akan semakin tinggi.

Pola asuh merupakan interaksi antara orang tua dengan anak, dimana orang tua berperan sebagai pemberi dorongan bagi anak dengan mengubah pengetahuan, tingkah laku, dan yang dianggap paling tepat bagi orang tua adalah agar anak bisa mandiri, memiliki rasa percaya diri yang tinggi, dapat tumbuh atau berkembang secara optimal dan berorientasi untuk sukses (Arub, 2017).Menurut Juhardin (2016), mengatakan beberapa faktor yang dapat mempengaruhi pola asuh pada orang tua, yaitu tingkat ekonomi orang tua, tingkat pendidikan orang tua, kepribadian orang tua, dan jumlah anak. Pola asuh orang tua pada umumnya terdiri dari 3 macam, yaitu pola asuh permisif, otoriter dan demokratis. Dengan ini dapat disimpulkan gaya pola asuh orang tua sangat berpengaruh terhadap perbedaan tingkah laku baik dan tidak baik pada masing-masing remaja (Triandika, 2015). 
Berdasarkan hasil penelitian dapat diketahui bahwa dari 100 responden mayoritas memiliki perilaku seks bebas tidak baik sebanyak 54 orang (54\%), sedangkan yang memiliki perilaku seks bebas baik sebanyak 46 orang (46\%). Menurut (Sari, 2016), perilaku seks bebas merupakan cara untuk mengekspresikan dan melepaskan hasrat seksual, seperti berkencan dan berhubungan intim. Beberapa tahap seseorang melakukan perilaku seks bebas, yaitu seperti berciuman dengan memegang payudara atau melalui oral seks pada alat kelamin, tetapi belum bersenggama, neckingbercumbu sampai menempelkan alat kelamin dengan saling menggesekkan alat kelamin satu sama lain namun belum bersenggama, petting yang sudah bersenggama dan sexual intercourse melakukan sesuatu di luar hubungan pernikahan(Sarwono, 2011).Faktor yang dapat mempengaruhi seorang remaja melakukan hubungan seksual, yaitu faktor religiusitas, faktor hubungan antara orang tua dengan remaja, perubahan hormonal, rasa ingin tahu yang tinggi pada remaja, dan faktor lingkungan pergaulan yang salah (Ningsih et al., 2018).

Berdasarkan hasil analisis data statistik uji Chi Square mengenai perbedaan pola asuh permisif dan otoriter orang tua terhadap perilaku seks bebas pada remaja di SMK Prima Bakti Citra Raya dari 100 responden didapat sebanyak 52 responden dengan pola asuh permisif memiliki perilaku seks bebas tidak baik, 36 responden dengan pola asuh permisif memiliki perilaku seks bebas baik, untuk pola asuh otoriter sebanyak 2 responden memiliki perilaku seks bebas tidak baik dan 10 responden memiliki perilaku seks bebas baik. Sedangkan hasil bivariat dengan menggunakan uji analisis Continuity Correction didapatkan hasil $(\mathrm{p}=0.014<0.05)$, sehingga terdapat perbedaan pola asuh permisif dan otoriter orang tua terhadap perilaku seks bebas pada remaja di SMK Prima Bakti Citra Raya Tahun 2020. Dengan nilai OR 0.813, maka pola asuh permisif orang tua memiliki 0.8 kali lebih rendah terhadap perilaku seks bebas pada remaja dengan nilai mean 1.59 dan untuk pola asuh otoriter orang tua memiliki 5.8 kali lebih besar terhadap perilaku seks bebas pada remaja dengan nilai mean 1,17. Hasil penelitian ini sependapat dengan penelitian yang dilakukan oleh (Suparni, 2015), bahwa dari 76 responden menunjukkan ada hubungan positif yang terjadi antara pola asuh permisif dengan sikap seks bebas, dengan hasil $t$ hitung $0.297<t$ tabel 0.05 maka rxy dinyatakan signifikan. Sehingga dapat disimpulkan semakin tinggi pola asuh permisif orang tua maka sikap perilaku seks bebas pada remaja juga akan semakin tinggi. Hasil penelitian ini juga sependapat dengan penelitian (Bintang, 2018), dari 350 responden menunjukkan hasil p-value $0.000<0.05$, selain itu dapat dilihat nilai dari masing masing pola asuh otoriter 29.16dan pola asuh permisif 30.43 hal ini menunjukan bahwa pola asuh permisif memiliki resiko tinggi terhadap perilaku seksual pranikah.

Gaya pola asuh orang tua yang memberikan kebebasan pada anaknya dapat membuat anak melakukan hal yang mereka inginkan dengan sesuka hati tanpa adanya pengawasan orang tua itu sendiri dan cenderung melakukan pergaulan bebas. Kesalahan ataupun kenakalan yang saat ini banyak dilakukan oleh remaja, menjadi penyebab utama timbulnya perilaku, yaitu terletak pada kesalahan pola asuh orang tua selama usia perkembangan remaja (Juhardin, 2016).

\section{KESIMPULAN}

Pola asuh yang diterapkan pada 100 remaja di SMK Prima Bakti Citra Raya, yaitu sebanyak 88 remaja dengan pola asuh permisif dan 12 remaja dengan pola asuh otoriter. Pola asuh permisif maupun otoriter dapat mengakibatkan perilaku seks bebas pada remaja. Dari hasil penelitian di SMK Prima Bakti Citra Raya pola asuh permisif yang diterapkan pada 88 remaja menyebabkan perilaku seks tidak baik sebanyak 52 remaja, sedangkan yang memiliki perilaku seks yang baik sebanyak 36 remaja. Sedangkan pola asuh otoriter yang diterapkan pada 12 remaja di SMK Prima Bakti Citra Raya menimbulkan perilaku seks tidak baik sebanyak 2 remaja dan 10 remaja yang memiliki perilaku seks yang baik. Hasil penelitian menunjukkan bahwa perilaku seks bebas pada remaja tersebut mayoritas memiliki perilaku seks bebas tidak baik sebanyak 54 remaja (54\%), sedangkan yang memiliki perilaku seks bebas yang baik sebanyak 46 orang $(46 \%)$.

Hasil uji Chi Square didapatkan hasil ( $\mathrm{p}=0.014<0.05)$, dengan nilai OR 0.813, maka pola asuh permisif orang tua memiliki 0.8 kali lebih rendah terhadap perilaku seks bebas pada remaja dan untuk pola asuh otoriter orang tua memiliki 5.8 kali lebih besar terhadap perilaku seks bebas pada remaja. 
Sehingga dapat disimpulkan ada perbedaan yang signifikan antara pola asuh permisif dan otoriter orang tua terhadap perilaku seks bebas pada remaja di SMK Prima Bakti Citra Raya.

Bagi para orang tua diharapkan dapat menerapkan pola asuh demokratis agar anak tidak merasa tertekan maupun terlalu diberikan kebebasan tanpa kontrol orang tua. Hal tersebut dapat diterapkan dengan memberikan pendidikan kesehatan kepada remaja maupun orang tua untuk mengetahui pentingnya pengetahuan dan informasi tentang kesehatan reproduksi, sehingga remaja tidak terjerumus ke dalam pergaulan bebas.

\section{DAFTAR PUSTAKA}

Ahiyanasari Citra Ervina Ira, Ira Nurmala. (2018). The Intention of Female High School Students to Prevent Premarital Sex. Jurnal Promkes. 5(1). 39. https://doi.org/10.20473/jpk.v5.i1.2017.39-52.

Arub Lathifah. (2017). Hubungan Pola asuh Orang tua dengan Perilaku Seksual Remaja di SMK Negeri 1 Sewon Bantul. Skripsi Universitas Aisyiyah Yogyakarta, 1-13.

Bintang Fatimah. (2018). Perbedaan Pola asuh Orang tua pada perilaku seksual Pranikah Mahasiswa yang Merantau. Diss University of Muhammadiyah Malang.

Department of Health and Human. (2018). Adolescent and School Health: Sexual risk Behaviors HIV, STD, \& Teen Pregnancy prevention. https://www.cdc.gov/healthyyouth/sexualbehaviors/index.html.

Devi Gadis Rozyta, Suci Musvita Ayu. (2015). Hubungan Pola asuh Orang tua dan Paparan Media Massa dengan Perilaku Seksual. 1-9.

Juhardin H, Suharty Roslan. (2016). Dampak Pola asuh Orang tua terhadap Perilaku Anak . Jurnal Neo Societa, 2(4).

Ningsih Pratiwi, Sri Utami, \& Nurul Huda. (2018). Pengaruh pendidikan kesehatan metode permainan Redi (Roda Edukasi dan Inspirasi) terhadap Pengetahuan Remaja putri untuk mencegah Seks Pranikah. JOM FKp, 5(3) : 563-571.

Pandensolang Santalia, Rina Kundre, Wenda Oroh. (2019). Hubungan Pola asuh Orang tua dengan Perilaku Seksual pada Remaja di SMA Negri 1 Beo Kepulauan Talaud. 7(1): 1-9.

Putri Fildzah Rudyah. (2018). Hubungan Pola asuh Otoriter terhadap Perilaku Perundungan pada Remaja. JKKP (Jurnal Kesejahteraan Keluarga dan Pendidikan), 5(2) : 101-108. https://doi.org/10.21009/jkkp.052.01

Rahmawati Iis, Dewi Suminar Retno, Oedojo Soedirham, Pingky Saptandari W. (2018). Confirmatory Factor Analyses of Adolescent Education Character by Families/Parents In Premarital Sexual Prevention In Jember, Indonesia. NurseLine Journal, 3(2), 89. https://doi.org/10.19184/nlj.v3i2.8694

Sari Yuni Mustika, and Yuni Purwati. (2016). Studi komparasi Perilaku Seksual Bebas berdasarkan Jenis kelamin Remaja Tunagrahita di SLB N 2 Yogyakarta. Universitas Aisyiyah Yogyakarta.

Sarwono Sarlito W. (2011). Psikologi Remaja edisi revisi. Jakarta: Rajawali Persada

SDKI, KRR. (2017). Survei Demografi dan Kesehatan Indonesia 2017: Kesehatan Reproduksi Remaja. Badan Kependudukan Dan Keluarga Berencana Nasional, 1-606. http://www.dhsprogram.com.

Triandika Sriadi, Annastasia Ediati. (2015). Kecenderungan Pola asuh Permisif dan Perilaku Seksual Pranikah pada Remaja Putri. Empati, 4(4) : 44-49.

Tridhonanto, Al \& Beranda Agency. (2018). MengembangkanPola asuh Demokratis. Jakarta: Pt Elex Media Komputindo 
World Health Organization. (2017). Recommendations on adolescent sexual and reproductive health and rights. https://apps.who.int/iris/bitstream/handle/10665/275374/9789241514606-eng.pdf?ua=1) 